\title{
UNA NOVELA LÍRICA DE LA TIERRA DE LOS FARAONES: LA SERPIENTE DE EGIPTO, DE ISAAC MUÑOZ
}

\author{
Amelina CORREA RAMÓN
}

Universidad de Granada

\section{RESUMEN}

En el año 1997 vio la luz por primera vez La Serpiente de Egipto, una novela lírica de temática orientalista, inspiración decadente y adscrita sin duda alguna a una intensa corriente egiptófila que atraviesa todo el siglo XIX. Su autor había sido el novelista granadino Isaac Muñoz (1881-1925), amigo íntimo de Francisco Villaespesa, y compañero de éste en la apasionada empresa de renovación literaria que propició la consolidación del modernismo en España, y cuya trayectoria vital y literaria ofrece un indudable interés, y, sobre todo, muestra su evidencia como síntoma de la época. Síntoma, en definitiva, de la crisis de fin de siglo, Isaac Muñoz plasma en su creación literaria las contradicciones, ambigüedades y deseos insatisfechos que marcaron la cultura de una etapa fecunda.

Palabras clave: Orientalismo, decadentismo, fin de siglo, novela lírica, egiptofilia

\section{ABSTRACT}

In 1997 it was published for the first time La Serpiente de Egipto, a lyric novel of Orientalist theme, decadent inspiration and undoubtedly attached to a strong flurry of Egyptphilia spread through the entire nineteenth century. Its author was the novelist from Granada Isaac Muñoz (1881-1925), a close friend of Francisco Villaespesa, and his companion in the exciting venture of literary renewal that led to the consolidation of Modernism in Spain. His life and literary career offer a clear interest, and, above all, show its evidence as a sign of the times. Symptom of the fin-de-siècle crisis, Isaac Muñoz captures, in his literary creation, the contradictions, ambiguities and unsatisfied desires that marked the culture of a fruitful period.

Key words: Orientalism, Decadent Movement, fin de siècle, lyric novel, Egyptphilia. 
Iluminada de aquel modo, la sala dorada resplandeció y, quizá por primera vez, los colores de sus pinturas refulgieron en toda su luz. Sobre aquella especie de barniz de oro que servía de fondo a las figuras y a los jeroglíficos destacaban rojos, azules, verdes y blancos de destello nuevo, de frescura virginal, de pureza inaudita, y cautivaban los ojos antes de haber podido discernir los motivos que su agrupación componía (Gautier, 1993: 112).

Con estas palabras describirá en 1858 el escritor francés Théophile Gautier, cultivador de la parnasiana religión del Arte por el Arte, las sensaciones que suscitan las imágenes de la tumba egipcia completamente intacta que descubre el joven Lord Evandale, protagonista de su narración orientalista La Novela de la Momia. Según Gautier, quien utiliza una expresión shakesperiana que remite a la escena en que Hamlet, trastornado, acaba de presenciar la aparición del espectro de su difunto padre, cuando el noble británico traspasa los umbrales que habían permanecido inviolados durante siglos de silencio, le pareció «que la rueda del tiempo se había salido de su carril» (Gautier, 1993: 111) ${ }^{1}$. Así, experimentará una vehemente e intensa emoción, sintiendo vivamente que «Una mano invisible había dado la vuelta al reloj de arena de la eternidad» (Gautier, 1993: 111).

De alguna manera, la rueda del tiempo pareció salirse también de su carril para mí, en una peculiar experiencia, en buena medida inefable -como supongo que lo son todos los descubrimientos-, que tiene que ver de igual modo con el Egipto que evoca la novela de Gautier, aunque en mi caso sólo haya intervenido la arqueología literaria y aunque mi esplendoroso hallazgo no consistiera en la momia de una bella dama hija de un alto sacerdote -esa «hermosa muerta» a la que alude el texto-, sino en un no menos hermoso manuscrito inédito de una novela adscrita al modernismo decadente en su vertiente orientalista, y titulada La Serpiente de Egipto. Su autor había sido el novelista granadino Isaac Muñoz ${ }^{2}$, amigo íntimo de Francisco Villaespesa, y compañero de éste en la apasionada empresa de renovación literaria que propició la consolidación del modernismo en España. Un nombre que casi nadie, excepto algunos amantes de las rarezas bibliográficas, parecía ya conocer. Sin embargo, la trayectoria vital y literaria de este escritor ofrece un indudable interés, y, sobre todo, muestra su evidencia como síntoma de la época. Síntoma, en definitiva, de la crisis de fin de siglo, Isaac Muñoz plasma en su crea-

1. En efecto, la expresión está contenida en el parlamento final de Hamlet al término de la Escena Quinta del Acto Primero: «The time is out of joint».

2. Para un análisis completo de su trayectoria biográfica y literaria, cf. CORREA RAMÓN, 1996. 
ción literaria las contradicciones, ambigüedades y deseos insatisfechos que marcaron la cultura de una etapa fecunda.

Inmersa por completo en una investigación en buena medida detectivesca que se inició a comienzos de 1991, logré averiguar tras una larga búsqueda que los orígenes familiares del escritor se hallaban en la localidad castellana de Tendilla (Guadalajara), donde el fundador de su linaje, Don Juan de la Plaza Solano, Secretario Real de Hacienda del rey Felipe V, construyera su palacio a comienzos del siglo XVIII, instituyendo en él el Mayorazgo de la Sacra Familia. Allí han permanecido los Muñoz de Solano desde entonces, y allí pude encontrar a una de las sobrinas nietas de Isaac Muñoz cuando viajé por primera vez a la localidad en julio de 1992. La emoción del descubrimiento resultó, ciertamente, estimulante, al reconocer, además, en la mansión solariega el escenario que aparecía en varias de las novelas de Muñoz ${ }^{3}$.

Pero aún me quedaba por encontrar la presencia más intensa, la más importante que, de Isaac Muñoz, se había conservado en la casona de Tendilla: sus propios libros, que hallé como vestigios yacentes sobre un arcón, pero primorosamente encuadernados por orden de su hermano menor, que lo quería y admiraba a pesar de lo diferente de sus personalidades y del distanciamiento familiar que el escritor había experimentado durante sus últimos años de vida. El deseo de conservar intacta la memoria de su hermano Isaac, fallecido prematuramente en 1925, llevó a Pablo Muñoz a encargar a un habilidoso artista, llamado José Panadero, la ilustración y encuadernación de las cubiertas de todos los volúmenes salidos de su pluma que la familia pudo recopilar. Y aquí sería cuando mis indagaciones literario-detectivescas adquirirían un nuevo y magnífico sesgo, pues, conociendo ya la mayoría de las obras de Muñoz por haberlas consultado en la Biblioteca $\mathrm{Nacional}^{4}$, al extraer de su refinado estuche el volumen de mayor tamaño de cuantos allí había, descubrí un original manuscrito cuyo título, La Serpiente de Egipto, me resultaba por completo desconocido. Se trataba, como luego de un análisis grafológico pude confirmar, de un texto que había permanecido inédito desde que su autor lo concluyese. Es decir, tenía entre mis manos una novela que había redactado

3. Desde fecha reciente, se ha otorgado espacio propio a la figura del escritor en una completa página web dedicada al la localidad de Tendilla, que se puede consultar en la siguiente dirección de Internet: <http://www.uam.es/personal_pdi/ciencias/depaz/mendoza/teisaacm.htm>.

4. No obstante, también fue útil la biblioteca de Tendilla para conseguir otras dos obras de Isaac Muñoz que había resultado imposible conseguir por otros medios: Colores grises, 1898 y Voluptuosidad, 1906. 
de su puño y letra Isaac Muñoz, y que había dejado preparada para imprenta, sin que, por razones que se nos ocultan, llegara nunca a ver editada ${ }^{5}$.

Ante mis ojos, al igual que había sucedido ante los del personaje literario de Lord Evandale, refulgía deslumbrante el hallazgo inusitado. Así, tras décadas de olvido, parecía ponerse en marcha de nuevo el reloj de la historia para una novela cuyo tiempo había quedado detenido muchos años atrás, depositada como estaba en la hermosa urna polícroma de su envoltura egiptizante . $^{6}$

Pues, en efecto, el artífice de la encuadernación y el estuche a juego se inspiró para su creación en motivos típicos del Antiguo Egipto -como las pirámides, la flor de loto, el uraeus o cobra real del tocado faraónico, la cruz egipcia de la vida, o ankh, etc.-, ya que la novela de Isaac Muñoz responde plenamente a esa egiptofilia tan en boga durante todo el siglo XIX y que, en su vertiente artística y literaria constituye una especialización del exotismo consolador en que se refugiarán multitud de exquisitos poetas de la palabra o el pincel a partir del Romanticismo. Y es que, como ya afirmara el propio Théophile Gautier:

Hay dos tipos de exotismo, el primero da el gusto por el desplazamiento en el espacio, la atracción por América, por las mujeres amarillas o verdes. Pero hay un placer más refinado, una corrupción más suprema, es el exotismo a través del tiempo (GAUTIER, 1863: 124; Apud LiTVAK, 1985: 43).

Y ese exotismo a través del tiempo es el que propiciará el descubrimiento de una civilización como la del Antiguo Egipto, que contenía todos los ingredientes para fascinar a los autores del XIX, hasta llegar con su capacidad de seducción intacta hasta los hiperestésicos modernistas. Así lo explicará líricamente el propio Isaac Muñoz en un artículo publicado en 1915 en el periódico Heraldo de Madrid:

«Quien ha bebido las aguas del Nilo, vuelve». Tal dice un viejo proverbio egipcio cuya verdad tiene toda la profunda sabiduría del Oriente madre. No todos los que han bebido las dulces aguas verdes tornan; pero raro es el que no siente en la distancia el recuerdo de su encanto.

5. Se trata de un manuscrito compuesto por ciento veintitrés páginas escritas por una sola cara, con una caligrafía esmerada y cuidadosa (la caligrafía que Isaac Muñoz solía emplear para documentos oficiales, ya que poseía otra de uso más privado que manifiesta una clara inspiración de la escritura árabe). No contiene apenas tachaduras, y presenta subrayadas las palabras que debían ir en cursiva, lo que permite suponer que se trataba de un texto preparado para la imprenta.

6. De hecho, el proceso de publicación de la novela, que, como ya se ha adelantado, parece haber iniciado en su momento Isaac Muñoz, pudo finalmente concluirse con la edición de la obra setenta y dos años después de la muerte de su autor. Cf.: MUÑOz, 1997. 
El Egipto atrae, no tanto por el deslumbramiento heroico de su historia como por el divino hechizo de su luz, por la eternidad de su paisaje, por su misterio, por su indefinible y suprema gracia oriental.

Prescindiendo del interés pura y descarnadamente arqueológico, es difícil determinar de un modo específico en donde reside el milagroso poder de la atracción de esta tierra maravillosa. ¿En su belleza original e imprevista? ¿En sus preciosas reliquias del pasado? (Muñoz, 1915).

En efecto, esa «tierra maravillosa», descubierta para Europa a raíz de la frustrada campaña que emprendió en ella Napoleón entre 1798 y 1799, exhibía ante los fascinados ojos occidentales el prestigio de su escritura oculta y sagrada, la complejidad de una riquísima narración mitológica, la belleza de un arte fastuoso y, muy importante, una conexión profunda y misteriosa con el mundo de los muertos, con una concepción de la ultratumba muy vívida y omnipresente, pero a la vez arcana. A partir de la publicación paulatina de los veintiún volúmenes de la Descripción del Egipto que Napoleón había encargado a un centenar de hombres de ciencia y de arte, y que fueron apareciendo entre 1809 y 1813, la civilización egipcia fue revelándose ante una Europa decimonónica que la acogió con verdadero fervor. A partir de esa fecha van a ir sucediéndose las excavaciones en el Valle de los Reyes, el hallazgo de momias reales, los avances en la interpretación de los jeroglíficos, y estudios de todo tipo que serán acogidos por la sociedad occidental con entusiasmo expectante. El prestigio del Antiguo Egipto crecerá hasta el punto de que su influencia acabará penetrando en casi todos los ámbitos de la vida europea. No serán tan sólo el arte, la literatura o la música -que dará ejemplos tan notables de la pasión por Egipto como la Aída de Giuseppe Verdi, estrenada en El Cairo en 1871, pero también las muy notables óperas Thaïs (1894) o Cleopatra (1914), del compositor francés Jules Massenet ${ }^{7}-$ sino que también la publicidad, la moda, los usos sociales ${ }^{8}$, la joyería y, cómo no, una

7. En el ámbito español, y aunque evidentemente dotada de un carácter muy diferente, «Sin duda, la manifestación más conocida de la egiptomanía española es La Corte de Faraón, zarzuela con música del maestro Lleó y libreto de Perrín y Palacios -inspirado al parecer en una olvidada opereta francesa titulada Madame Putifar- cuyo estreno tuvo lugar en el Teatro Eslava de Madrid el 21 de enero de 1910» (Saguar Quer, 2006: 293-294).

8. Así, por ejemplo, conviene señalar cómo durante buena parte del XIX se puso de moda entre las acomodadas sociedades francesa y británica reunirse para proceder al desenvolvimiento de una momia egipcia, que eran traídas entonces en cantidades ingentes y acerca de las cuales -excepto en los casos de momias reales o de las altas jerarquías- se desconocía, con un arrogante punto de desprecio eurocéntrico, su verdadero valor. De este modo, el escritor argentino Norberto Luis Romero recuerda en una de sus narraciones que, «En efecto, el mayor refinamiento y esnobismo que podía exhibirse por entonces en una fiesta de aristócratas que se preciara de serlo, consistía en desenvolver 
arquitectura que se caracterizará a lo largo de un siglo por todos los posibles revivals del pasado, del neogótico al neomudéjar, pasando también, cómo no, por el neoegipcio (valga el neologismo...). La variedad resulta tan sorprendente que Carlos Saguar, estudioso en profundidad del fenómeno, proclamará en un reciente artículo:

En el anchuroso campo de la egiptomanía puede encontrarse de todo: el máximo refinamiento y el kitsch más depravado, remedos ingenuos, eruditas y alambicadas combinaciones, adaptaciones pretendidamente miméticas y despropósitos delirantes, fantasía, frivolidad, humor. Por hablar de arquitectura, las formas egipcias han sido reutilizadas -de San Petersburgo a Sydney, de Estocolmo a Maracaibo, de Nueva Cork a París- en las obras más dispares: monumentos públicos, jardines, pabellones de exposiciones, entradas de cementerios, mausoleos, iglesias protestantes, sinagogas, monumentos de Semana Santa, logias masónicas, casas particulares, palacios, fábricas de hilaturas, bibliotecas, museos, cárceles, puentes colgantes, palacios de Justicia, observatorios astronómicos, parques zoológicos, farmacias, hoteles, teatros, cines, casinos... con «justificación» más o menos razonable o sin más pretexto que su irresistible atracción sobre el imaginario colectivo (Saguar Quer, 2006: 295).

Es en ese contexto donde habría que situar la novela La Serpiente de Egipto. Heredera, de alguna forma, de otras anteriores, como El sortilegio de Karnak, que Isidoro López y José Ramón Mélida habían publicado en $1880^{9}$, sin embargo, la obra de Isaac Muñoz se distancia claramente del afán arqueológico perseguido por sus antecesores, preocupado por encima de todo por la calidad literaria de su texto, escrito -como solía ser habitual en sus narracionesen una prosa refinada y exquisita, morosa, llena de matices poéticos, lo que convierte sin lugar a dudas a La Serpiente de Egipto en la novela lírica que hoy estudiamos aquí ${ }^{10}$.

ante los invitados atónitos una momia traída de Egipto. Abundaban de tal forma estas reliquias en los desiertos, que los barcos llegaban a Liverpool cargados de sarcófagos cuya dudosa utilidad hacía que acabaran en su mayor parte en los hornos de los telares a vapor de las industrias textiles de Inglaterra» (Romero, 2006: 604).

9. En relación con esta curiosísima obra, que sus autores subtitulan significativamente Novela arqueológica, se puede consultar la siguiente bibliografía: Litvak, 1990, y Casado Rigalt, 2006.

Se puede señalar también como muestra del enorme interés que la cultura del Antiguo Egipto despertó en José Ramón Mélida, que éste pronunció una conferencia sobre el tema cuatro años después de la publicación de la novela en el Ateneo de Madrid: $\mathrm{La}$ religión egipcia. Conferencia leída en el Ateneo Científico, Literario y Artístico de Madrid la noche del 6 de mayo de 1884 (1884).

10. Para el caso concreto de la literatura andaluza, donde se encuadra Isaac Muñoz, esta situación ha sido estudiada por GRARD, 1992. 
De hecho, como ya se ha adelantado, toda la producción literaria de Isaac Muñoz va a caracterizarse por ese lirismo, propio, por otro lado, de la renovación estética emprendida por el modernismo. Ese factor contribuirá en buena medida a que sus novelas no encuentren la aceptación por parte del público lector mayoritario, acostumbrado a otro tipo de obras de estructura, planteamiento y estilo mucho más asequibles. Muñoz, siempre inconformista y poco acomodaticio, inmerso en la profunda crisis de entresiglos, representa sin duda alguna el anhelo de innovación frente a una narrativa aún anclada en los modos literarios decimonónicos.

Para comprender la situación en que se encontraron las obras de Muñoz en el contexto de su época quizás resulte fructífero recordar unas palabras de José Ortega y Gasset, cuyo contenido resulta extrapolable al escenario aquí dibujado:

Cuando el pensamiento se ve forzado a adoptar una actitud beligerante contra el pasado inmediato, la colectividad intelectual queda escindida en dos grupos. De un lado, la gran masa mayoritaria de los que insisten en la ideología establecida; de otro, una escasa minoría de corazones en vanguardia, de almas alertas que vislumbran a lo lejos zonas de piel aún intactas. Esta minoría vive condenada a no ser bien entendida: los gestos que en ellas provoca la visión de los nuevos paisajes no pueden ser rectamente interpretados por la masa de retaguardia que avanza a su zaga y aún no ha llegado a la altitud desde la cual la terra incognita se otea. De aquí que la minoría de avanzada viva en una situación de peligro entre el nuevo territorio que ha de conquistar y el vulgo retardatario que hostiliza a su espalda (Ortega y Gasset, 1923: 15-16).

A «esa escasa minoría de corazones en vanguardia» perteneció, sin duda alguna, Isaac Muñoz, quien, frente a una mayoría de escritores cuya esencial preocupación no era otra que la de crear una literatura de evasión, fácil y despreocupada, que conectara sin dificultad con un público sin ambiciones, eligió la originalidad de una voz personal. Así, se le puede situar en el escaso conjunto de autores que, como Valle-Inclán, Azorín, Ramón Pérez de Ayala o Gabriel Miró, optó por el intento de ruptura con las técnicas novelísticas clásicas. Este nuevo tipo de obra, tan renovadora como poco comprendida en el periodo finisecular, surge de la voluntaria transgresión de las premisas esenciales consideradas necesarias hasta el momento para la escritura de una novela, rompiendo en buena parte con la rígida separación de géneros y conjugando poesía y prosa, dentro de una concepción distinta del valor de la palabra $^{11}$.

11. La cita reproducida se refiere, en realidad, a la novela Flor de santidad (1904), de ValleInclán -tan admirado, por otro lado, por el propio Isaac Muñoz-, aunque se pueda aplicar perfectamente a las características de la producción narrativa de este último. 
De ahí las numerosas críticas negativas que recibirán este tipo de obras, censuradas por su exceso de preciosismo y su cercanía con el género lírico. Así por ejemplo, se puede recordar la reseña que el prestigioso crítico literario Eduardo Gómez de Baquero, Andrenio, dedicó en 1908 a la recién aparecida novela Morena y trágica, donde Isaac Muñoz refleja la desventurada historia de amor entre una gitana del Sacromonte granadino y un misterioso joven de ascendencia judía, todo ello marcado por un refinado erotismo decadente y escrito en una prosa esteticista y suntuosa:

Más que novela, Morena y trágica -su autor, Don Isaac Muñoz- es un poema en prosa, una transposición del lenguaje poético a la novela, una serie inacabable de imágenes, de figuras, de remembranzas literarias e históricas [...]. El Sr. Muñoz tiene innegables condiciones de escritor, y a pesar del preciosismo empalagoso de Morena y trágica, hay en este libro pasajes bellos e intensos, pero sigue un camino equivocado, de que le conviene apartarse para hacer obras más verdaderas y naturales (Gómez de Baquero, 1908).

El tan denostado preciosismo, artificio que merece el franco rechazo de la crítica literaria al uso, constituye, efectivamente, una de las características más evidentes a nivel formal de las novelas de Isaac Muñoz. Sus difusos argumentos quedan diluidos entre las minuciosas descripciones de escenas extraordinariamente sensoriales y plásticas. Así pues, resulta procedente traer a colación unas certeras palabras de Ricardo Gullón, procedentes precisamente de su obra La novela lírica, quien explica que en este tipo de obras:

Lo narrativo (escaso) está embebido en lo lírico, disuelto en la corriente de imágenes; sólo a través de ellas se siente su presencia. En el instante que es la escena, y en la sucesión de éstas, todo se subordina a la presentación fiel de la visión y no a las expectativas de un desarrollo que acaso no tenga lugar. La continuidad de la visión es el factor unificante y la razón de que el texto no sea una acumulación de poemas en prosa, sino la historia que el narrador se propuso contar, situándola más allá del tiempo, en los confines donde realidad y símbolo se encuentran y se abrazan como en espacio de natural coincidencia (Gullón, 1984: 71).

En efecto, la producción novelística de Isaac Muñoz evidencia su continua preocupación por transmitir poéticamente la sensación recreada momento tras momento, preocupación muy superior a la de presentar un argumento sólidamente hilado. Él mismo reconoce que este modo de concebir la literatura le ocasionó agrias críticas durante toda su trayectoria como escritor. De ahí que en el prefacio de su novela Esmeralda de Oriente (1914), afirme categórico: «Ciertamente, con arreglo a los clásicos principios consagrados, mis libros no son novelas» (Muñoz, 1914: 9). En realidad, se manifiesta la voluntad clara del autor de distanciarse de los principios dogmáticos que parecían 
regir tanto el desarrollo formal como la materia que se juzgaba novelable. Isaac Muñoz se separa de las mayorías convencionales, de ese público lector que busca el texto ameno y que sigue al pie de la letra las convenciones establecidas. De ahí que proclame con cierto orgullo herido de quien se sabe radicalmente diferente:

No tengo filiaciones. Escribo a mi modo. Mis libros son motivos espirituales, y, nada más (Muñoz, 1914: 10).

«Motivos espirituales»; dicha concepción explica en buena medida el peculiar estilo literario de que hace gala Isaac Muñoz, un estilo, en efecto, casi versicular, y donde las frases cortas se yuxtaponen sin apenar nexos de subordinación, conformando párrafos usualmente muy breves. Las sucintas frases que componen su prosa poética contribuyen, sin duda alguna, a marcar un determinado ritmo, casi litúrgico en ocasiones, que se ve acentuado por el marcado predominio de verbos estáticos sobre los de acción. Todo ello supone evidentemente una ruptura con las normas retóricas imperantes, innovando con su ausencia casi total de conjunciones.

Así, Lily Litvak, en su estudio sobre la influencia del orientalismo en la España de finales del XIX y comienzos del XX, definirá del siguiente modo el estilo de este autor modernista:

El silencio se presenta también en la forma en que conversan los personajes, por medio de sentencias cortas, diálogos compuestos por saludos en árabe, y frases tajantes y fatalistas [...].

El estilo de Muñoz es un ejemplo de esta técnica llevada a su límite. Sus novelas se construyen por párrafos formados por una o dos frases tan sólo. Al flujo de las palabras y cadencias se opone un vocabulario y un ritmo estáticos, y la incansable repetición de las mismas palabras permite remontar a través de su sentido y sus matices hasta agotar el contenido intelectual y no guardar de ellas más que la sonoridad y sus realidades cualitativas (Litvak, 1985: 146-149).

Tanto la estructura y estilo formal de sus novelas como el contenido de las mismas encuentran su origen en la decidida voluntad que evidencia en todo momento Isaac Muñoz de escribir en una dirección otra, marcado por el sentimiento de alteridad que caracterizará su trayectoria personal, al igual que la de otros muchos compañeros generacionales. Así pues, enfrentado a la concepción del arte al servicio de una idea o de un propósito, el refinado escritor granadino no puede concebir otra forma de escritura que no sea la del arte por el arte, consagrando de este modo la literatura como una suerte de realidad sacral.

Posiblemente se pueda considerar que en este punto manifestara la influencia de dos autores que siempre fueron para él admirados maestros y que 
resultaron importantísimos en el mundo cultural del fin de siglo. Se trata de Friedrich Nietzsche y de Gabriele D'Annunzio ${ }^{12}$, defensores siempre de un arte exento de finalidades prácticas, más allá de su propia autenticidad.

De ahí que cuando Isaac Muñoz acometa la escritura de una novela como La Serpiente de Egipto, probablemente la última que saliera de su pluma y datada en torno a 1915-1916 ${ }^{13}$, no va a seguir los modelos anteriores de narraciones del estilo de El sortilegio de Karnak, puesto que, más que proceder a ambientar su obra con la perfección científica que perseguía la tendencia de literatura arqueológica al uso ${ }^{14}$, se pone de manifiesto que el objetivo que persigue primordialmente es el de recrear con sutilidad un ambiente, el de la antigua civilización egipcia, sugerente y misteriosa, con la que Europa soñaba desde hacía más de un siglo.

Esta función de recreación de un determinado ambiente la cumplen en el texto las descripciones de determinados lugares identificados inequívocamente con la realidad egipcia, como es el mítico río Nilo:

Millares de pelícanos, de garzas y de ibis, surgían de los lodazales, y se alejaban siguiendo la dirección del río sagrado.

En la fresca diafanidad del aire se presentía como una acre y remota brisa marina, y nubes densamente aterciopeladas parecían proyectar una sombra violeta sobre la tierra sedienta.

Lentamente caía la noche, y el Nilo, por el que ya no pasaba ni una barca de blancas velas como alas, diríase que se inmovilizaba en el recogimiento del crepúsculo (Muñoz, 1997: 121).

De igual modo, y evidenciando claramente haberse documentado con profusión, resulta habitual la inclusión de reiteradas alusiones a las distintas

12. Precisamente en el volumen I de su obra autobiográfica La novela de un literato Rafael Cansinos Assens se referirá de manera reiterada a Isaac Muñoz denominándolo «d'annunziano». Así, por ejemplo, en la página 78 se encuentra la siguiente cita: «Isaac Muñoz, el dannunziano, nos hablaba del gran Gabriele, y nos comunicaba su entusiasmo dionisíaco, su pagano amor a la vida, al placer y la muerte heroica y magnífica, en plena juventud».

13. La grafía que presenta el manuscrito de La Serpiente de Egipto revela un trazo firme y seguro. Dado que durante sus últimos años de vida el autor padeció sífilis en un estado avanzado, lo que le ocasionó lo que se conocía como «parálisis general progresiva» (o P.G.P.), parece muy improbable que escribiera esta novela en fecha posterior, ya que los documentos conservados desde 1917 evidencian ya un perceptible deterioro físico.

14. De hecho, y aunque resulta evidente que Isaac Muñoz llevó a cabo una importante labor de documentación acerca de la cultura y la historia egipcia, lo cierto es que obra contiene una serie de inexactitudes y errores históricos. Sin embargo, conviene tener en cuenta que en esas fechas todavía no se había establecido una cronología rigurosa y completa del Egipto faraónico, y tardaría aún bastante en establecerse la Egiptología como saber científico. 
divinidades egipcias (Amón, Apis, Isis, Anubis, Thot, Horus, etc.) y a los solemnes cultos religiosos llevados a cabo en sus santuarios:

A la luz ensangrentada de las antorchas surgían a veces de las tinieblas las moles enrojecidas de los templos, y entre las lenguas de fuego, aparecían a instantes anchas columnas pintadas de colores vibrantes, largas galerías en sombra pobladas de enigmas.

Lentamente, salían de los templos calvos y pálidos sacerdotes, vestidos de blanco, llevando en alto vasos encendidos.

Caminaban con paso grave y mesurado, y algunos fieles encendían sus lámparas en la luz de los vasos, llenos de aceite purificado por las manos sacerdotales (Muñoz, 1997: 125) ${ }^{15}$.

La Serpiente de Egipto está ambientada en la legendaria ciudad de Tebas, que solía aparecer frecuentemente en las novelas europeas surgidas de la fiebre egiptófila del XIX. Así, también El sortilegio de Karnak la tiene por escenario, y en cuanto a La Novela de la Momia, de Théophile Gautier, el papiro encontrado en el sarcófago de la bella Tahoser y que contiene su historia, comienza también la narración situándola en este importantísimo centro del poder político. Pues es cierto que la que Homero denominaría como «la de las cien puertas» para distinguirla de la Tebas griega, «de las siete puertas», fue una de las principales ciudades del Antiguo Egipto, centro de la cultura y la vida social y lugar de residencia de los faraones, que alcanzó poder político y religioso cuando los príncipes de la región impusieron su voluntad sobre todo el país y fundaron la XVIII dinastía, que supuso el Imperio Moderno, alrededor de 1567 a. C.

El momento en que se inicia la novela de Isaac Muñoz se sitúa simbólicamente al alba de un nuevo día con el que da comienzo el primer capítulo de los dieciséis en que la obra está estructurada:

Amanecía en la Tebas maravillosa de las Cien Puertas, en la ciudad máxima que concentraba cuanto había de más profundo y de más misterioso en la enigmática alma egipcia.

[...]

En esa hora incierta e inquietante del amanecer, la ciudad despertaba lentamente, y parecía que un denso velo envolviera las formas en una sombra

15. Se pueden recordar multitud de pasajes donde se mencionan explícitamente las divinidades del panteón egipcio, como por ejemplo: «Antes de salir de su morada, Thotmet acarició sus amuletos, y con el espíritu tenso, puramente elevado, invocó las tres veces de ritual al dios Ammon, de la gloriosa Tebas.

Una inquietud imprecisa y ondulante torturaba su espíritu y le angustiaba confusamente, pero al mismo tiempo pensaba con aliento consolador que Nephtys, Isis y Maskhuit, las tres buenas diosas habían asistido a su nacimiento, y ellas velarían porque sus días fuesen de luz y de amor» (Muñoz, 1997: 131). 
ambigua que aun participaba del misterio angustioso de la noche (Muñoz, 1997: 113-114).

En ese momento mismo del amanecer se presenta al lector a quien ha de ser el protagonista masculino de la novela, el príncipe Thotmet, héroe torturado e hipersensible característico de la literatura decadente tan del gusto de la época, quien considerándose más legitimado para ejercer el poder real, conspira con el misterioso y fiel Menhop y con el pueblo nómada de los hycsos -quienes, de origen semítico, lucharon por el dominio de Egipto, consiguiendo su objetivo entre las dinastías XV y XVI (1675-1580 a. C. aproximadamente)-. Thotmet pretende recuperar un trono que juzga usurpado ilegítimamente. $\mathrm{Pa}$ ra acercarse al palacio del faraón, el joven traba relación con Nikris, la favorita del harén real, una hermosa mujer tirana y ambiciosa, entregada a todos los placeres y carente por completo de escrúpulos. Thotmet comenzará fingiendo un amor que pronto se apoderará de él como un veneno. Así, la novela narra la anulación de la voluntad de un hombre valeroso y fuerte en manos de una mujer que acabará causando su perdición. En este sentido, La Serpiente de Egipto se asemeja en sus planteamientos a numerosas obras de la época, cuyos máximos ejemplos podrían considerarse novelas como Salambó (1862) de Gustave Flaubert, que tanta repercusión tendría sobre el orientalismo literario y que causó en el momento de su publicación un considerable escándalo, o Cleopatra (1889), de Rider Haggard. En ambas se narra la historia de la anulación de la voluntad de un hombre por parte de una mujer fascinadora y de poder casi hipnótico, que acaba llevándolo a la destrucción.

Así pues, el personaje de Nikris responde claramente al arquetipo tan finisecular de la mujer fatal: bella y tentadora, lujuriosa, independiente, cruel, egoísta y capaz de todo por conseguir satisfacer sus deseos. De ahí que a lo largo de toda la novela, desde el propio título, se relacione a esta seductora fémina con la serpiente, símbolo del mal, pero del mal que atrae seductoramente, de la tentación que cautiva y ofrece la manzana prohibida:

Vibraba la fascinadora entre los brazos del príncipe, y su cuerpo ondulante cubierto de plata, tenía la sinuosidad y el brillar metálico de una larga serpiente (Muñoz, 1997: 146).

Este beso lento, aterciopelado, que le dejó gustar todo el divino aroma venenoso de la maga, enloqueció al príncipe.

Ella se deslizó como una serpiente de plata, y desde el extremo del kiosco, le miró sonriente, llena de endemoniadas fascinaciones (Muñoz, 1997: 159.

Entonces Nikris, se irguió fina y radiante como la serpiente sagrada (Muñoz, 1997: 196). 
De ahí que el leal Menhop advierta al paulatinamente cegado príncipe: «Desconfía, Thotmet, desconfía siempre. Esa mujer es una maravillosa serpiente venenosa, y si se enrosca a tu cuello, te estrangulará» (Muñoz, 1997: 123).

La imagen simbólica de la serpiente asociada con la mujer ha sido una constante cultural a lo largo de los tiempos, tal y como constata Juan-Eduardo Cirlot: «Hay una evidente conexión de la serpiente con el principio femenino. Según Eliade, Gresmann [...] ha visto en Eva una diosa fenicia arcaica del mundo subterráneo, personificada por la serpiente [...]. Al propósito, relaciona el autor aludido las numerosas deidades mediterráneas que se representan llevando una serpiente en una o ambas manos (Artemisa Arcadia, Hécate, Perséfone), las sacerdotisas cretenses, bellamente figuradas en oro y marfil; o con los cabellos de serpientes (Gorgona, Erinias)» (Cirlot, 1985: 407).

En este punto no se puede evitar la mención de la célebre escena en la que se describe lúbricamente el baile litúrgico que tiene lugar entre la hermosa Salambó y una enorme serpiente pitón que se enrosca a su cuerpo. De hecho, fueron varios los artistas que retrataron la sugerente escena en cuadros o esculturas, como es el caso de Maurice Ferrari o del propio Alphonse Mucha ${ }^{16}$.

Así, en realidad el título de la novela de Isaac Muñoz hace alusión a la propia Nikris, que es presentada a lo largo de la obra como una «serpiente monstruosa que se enrosca y estrangula al Egipto entero» (Muñoz, 1997: 166) ${ }^{17}$.

En este sentido conviene señalar que La Serpiente de Egipto constituye una nueva muestra de la particular concepción del erotismo que caracterizaría a Isaac Muñoz durante toda su trayectoria ${ }^{18}$. Una concepción donde el placer amoroso parece estar siempre íntimamente asociado con la sangre y con la muerte, de manera en verdad muy llamativa. El erotismo que tantas veces rechazarían las más cerradas mentalidades de su época se configura en todo momento en escenas cinceladas por el más primoroso de los orfebres, un artista preocupado hasta el límite por el esteticismo y la belleza. Y es que, lejos de los sórdidos ambientes de prostitución y miseria descritos por la novela

16. Tituladas en ambos casos «Salambó», la primera es una escultura de 1899 del artista francés Maurice Ferrari donde la bella sacerdotisa aparece completamente desnuda, rodeado su cuerpo por la serpiente. La obra de Alphonse Mucha es un cuadro datado en 1896 que muestra a una mujer voluptuosa con torso desnudo, abundantemente alhajada, con un suntuoso tocado de plumas de pavo real.

17. Sobre la serpiente, así como otros animales presentes en la novela de Isaac Muñoz, se ha publicado recientemente en formato digital el siguiente artículo: SORBIER-RAWLS, 2009.

18. Un estudio pormenorizado acerca de esta personal concepción se encuentra en el capítulo titulado «Isaac Muñoz y el sentimiento de alteridad», en especial en los epígrafes «Sangre, amor y muerte», «El otro: la mujer» y «Perversiones sexuales. El camino de la alteridad», en el ya citado Correa, 1996: 135-242. 
naturalista, lejos del tono obsceno y con pretensiones de suscitar la excitación del lector característico de la novela pornográfica, el erotismo de Isaac Muñoz resulta en todo momento refinado y sutil.

Así lo explicaría en el segundo volumen de su reveladora obra La Nueva Literatura su contemporáneo y amigo, el muy polifacético Rafael Cansinos Assens:

este anhelo de incondicional belleza, es el anhelo de este joven, amante de lo raro y lo suntuoso, que en libros como La fiesta de la sangre canta el placer y la belleza de la crueldad, y en cuyos libros amatorios como Lejana y perdida se exalta el amor en sus formas más desgarradoras y torturantes, aquellas en que los cuerpos enlazados parecen cumplir ritos expiatorios y unirse, no para crear, sino para consumirse sin dejar ni una rosa del doble ramo carnal (Cansinos Assens, 1998: 288).

Ritos expiatorios, ceremonias sacrificiales, arcanos cultos en los que parece pedirse el favor divino mediante el derramamiento de la gloriosa sangre que representa la más pura esencia vital. Todo ello parece encontrarse en las numerosísimas escenas amatorias que se reproducen en las novelas de Isaac Muñoz:

Ante aquella carne ansiosa y fría, que se daba a la tortura, yo sentí puro, como en las primeras edades de la tierra, el absoluto goce bárbaro de los inmoladores.

Percibí cómo en la sangre está la más alta gracia de la vida. [...]

Y en cada espasmo de amor, vibran las tres divinas fuerzas de la vida, la alegría, la crueldad y la muerte (Muñoz, 1908: 109-110).

Así, los encuentros eróticos de sus novelas ofrecen sin lugar a dudas una indisoluble relación entre los tres elementos básicos: el amor como pasión creadora y redentora; la sangre como cauce de vida, que se puede derramar, y como paradójica dispensadora de placer y de dolor, inextricablemente unidos; y la muerte, como pasión destructora, y merced a ello, igualmente redento$\mathrm{ra}^{19}$. Su visceral comprensión del amor como fuerza que destruye y que salva constituye uno de los grandes ejes que da sentido a las obras de Isaac Muñoz. Los amantes se desean con tal fuerza que su amor sólo puede consumarse en el dolor. La fascinación por la muerte, por otro lado, planea incesante sobre el tálamo. Parejas que se abrazan sobre las tumbas de un cementerio, o que se

19. Quizás resulte ilustrativo incluir aquí a este respecto una cita de La metáfora y el mito, donde Ángel Álvarez de Miranda explica: «Para la mentalidad primitiva y arcaica todos los trances de al vida están dotados de sacralidad. Esos trances son en último análisis tres: vivir, engendrar y morir. Están íntimamente compenetrados entre sí y hallan su expresión en el sentido misterioso de la sangre (vida), el sentido misterioso de la muerte y el sentido misterioso de la fecundidad» (Álvarez de Miranda, 1963: 13). 
enlazan en una tormentosa cópula junto a un cadáver calcinado por el sol del desierto. Así, el estertor del placer se confunde con la agonía de la muerte ${ }^{20}$.

De este modo, en La Serpiente de Egipto se dice explícitamente de su protagonista femenina que «Nikris sabía que el amor humano no llega a su límite divino sino en la horrible agonía, [...] cuando nuestras pupilas aterradas contemplan ya la eternidad, cuando nuestras manos han vuelto a ser garras y sienten el ansia de la destrucción» (Muñoz, 1997: 170). Así mismo, Thotmet besa enfebrecido a la magnética Nikris, «con ansia feroz de morder la carne suave, y de sentir en los labios la humedad cálida y perfumada de la sangre» (Muñoz, 1997: 159) ${ }^{21}$.

Y es que Isaac Muñoz concibe el beso como un acto dotado de un profundo sentido trascendente. «Todo el divino perfume de la lujuria y de la muerte, me lo dio su boca que sangraba como un corazón» (Muñoz, 1908: 119), había dejado escrito ya años antes en su novela Morena y trágica.

La concepción que del amor demuestra Isaac Muñoz en sus creaciones evidencia una vez más la compleja relación entre Eros y Thanatos que resultó tan frecuente en la literatura modernista, una concepción del amor oscura y atormentada, que sólo parece encontrar su razón de ser en el completo extravío o en la muerte. El tema, como es bien sabido, fue ya planteado por Ricardo Gullón en su estudio clásico Direcciones del modernismo:

El erotismo, según supieron los poetas antes que los médicos y psicólogos, es en última instancia (es decir, cerebralmente) un ansia de trascendencia en el éxtasis, pero no solamente en el éxtasis del sentimiento, sino en el de los sentidos. Llevar la exaltación del gozo hasta el punto donde el yo se extingue; sentir el orgasmo como una muerte chica que prefigura la pérdida de conciencia en que el morir consiste [...].

El punto de coincidencia entre erotismo y misticismo es justamente la sombría necesidad de perderse en otra cosa $[\ldots]$.

Y el erotismo finisecular, sobre todo el de los entonces llamados decadentes, postula también un agotamiento que, de fantasía en fantasía, al negar la realidad, negará a quien la vive. La sensualidad deja de ser inocente para sentirse perversa y, en esa perversidad, metafísica. Ceder a ella es abrir las puertas $[\ldots]$, abandonarse a las fuerzas en que el Yo se diluye. Fusión con la energía destructora de la corrupción, opuesta a la del místico en sustancia,

20. En relación con este peculiar «Eros negro», cf. Litvak, 1979.

21. Por las mismas fechas de composición de La Serpiente de Egipto Rafael Cansinos Assens publicó una sorprendente obra titulada Estética y erotismo de la pena de muerte, donde se puede leer la siguiente conexión entre la sangre y el erotismo: «interviene, clara y manifiesta, la sangre humana, despertadora de instintos dionisíacos, misteriosamente relacionada con las renovaciones de la luna, madre, por ello, de misteriosas imágenes lascivas» (Cansinos Assens, 1916: 125). 
idéntica en tendencia y en finalidad: la aniquilación del ser en lo otro (Gullón, 1990: 85-86).

Y es que, en efecto, esa íntima unión entre sangre, amor y muerte que se encuentra en las novelas de Isaac Muñoz pareciera, en efecto, perseguir de algún modo, y trascender, la aniquilación individual:

Tendí mis labios y bebí la muerte en el manantial de su vena abierta.

Su sangre tenía el gustor acre y salobre de una ola, era amarga y pulposa, como una flor china de talictro.

$[\ldots]$

Y fue un beso lento en el que se confundieron nuestras sangres, un beso de agonía, de extenuación, de fiebre y de amor maldito (Muñoz, 1908: 110-111).

Como se puede comprobar, las escenas narradas por Isaac Muñoz, escasas en verbos -y en especial, en verbos de acción-, abundan en adjetivos sensoriales, que apelan a ese «éxtasis de los sentidos» al que se refería Gullón: «acre y salobre», «amarga y pulposa», pero también demuestran una recreación atenta a los matices y voluntariamente evocadora de un ambiente decadente y lujosamente esteticista. Así, sus descripciones serán minuciosas y ricas en imágenes que propician la plasticidad, predominando las alusiones a motivos florales, a animales exóticos, a piedras preciosas, a ricos metales, o a telas regias y fastuosas.

Así se presenta, por ejemplo, una escena festiva en el harén del palacio del faraón, territorio de dominio de su maquiavélica favorita:

Hermética y deslumbrante, Nikris pasó toda la tarde en el harén real, en donde invitó a las mujeres a una fiesta con motivo del cercano retorno del Faraon $[s i c]^{22}$.

Se celebró la fiesta en la más vasta sala de las estancias de la princesa.

Ardían millares de luces en altas y cinceladas lámparas de bronce, brillaban como esmaltes las suntuosas pinturas murales y las anchas columnas de capiteles lotiformes, relucía el suelo cubierto de polvo de oro, fulguraban las esmeraldas, las turquesas, los rubíes, que constelaban las morenas carnes femeninas.

Innumerables flores espléndidas, esparcidas por el suelo, por las mesas, por los divanes, confundían sus perfumes violentos con el olor denso

22. A lo largo de todo el texto de La Serpiente de Egipto, al igual que sucede en El sortilegio de Karnak, la palabra «faraón» aparece escrita siempre con mayúscula inicial y sin acento, probablemente porque se entendiera en la época como palabra exótica, no sujeta aún a las normas del español. En El sortilegio de Karnak, además, se utiliza siempre sin artículo, como si se tratara de un nombre propio, siguiendo la tradición del texto bíblico (cf. Génesis y Éxodo), al igual que sucede en la ya citada zarzuela cómica $L a$ Corte de Faraón. 
y turbador de las jóvenes carnes de mujer, de las anchas y negras cabelleras crepitantes.

En los extremos de la sala, dos gentiles surtidores de mármol, elevaban un agua aromada de frescas esencias, que dulcificaba la excesiva morbidez del aire.

De lejanías invisibles, llegaban músicas desmayadas y nostálgicas (Muñoz, 1997: 194).

Las diversas citas de La Serpiente de Egipto reproducidas hasta aquí permiten poner de manifiesto el hecho constatable de que su autor fue, sin duda, un escritor raro en el sentido de inusual, de extraño o distinto, siguiendo en este último caso una denominación de origen juanramoniano ${ }^{23}$. En efecto, su estilo permanece radicalmente inconfundible, un estilo tan personal que contiene, según Luis Antonio de Villena, «la prosa más decadente y enjoyada de nuestro modernismo simbolista, en su matiz orientalizante»(Villena, 2001: 195). Así, Villena saludó la primera publicación de La Serpiente de Egipto, tantos años después de su escritura, y haciendo alusión a las peculiares circunstancias que rodearon su hallazgo, como una «auténtica joya de prosa lírica -absorbente, ingenua, brutal- hallada en el barro» (Villena, 2001: 196). Y concluía: «Un regalo rarísimo» (Villena, 2001: 196).

Y es que la prosa lírica de Isaac Muñoz, que tan poca estima encontró en el ánimo del público común de su época, ha seguido consiguiendo lectores devotos que la han degustado, entonces y ahora, ciertamente, como un licor excesivo y penetrante, que aturde y marea, pero también seduce. Pues ya lo había dejado señalado en 1917 Rafael Cansinos Assens, con unas palabras que pueden servir de adecuado broche final:

Suntuosidad y erotismo son las virtudes predominantes de este escritor, que en cada uno de sus libros supera lo más tendidos y fructuosos esfuerzos de los preciosistas y está tan colmado de perlas y diamantes y los lanza con tal prodigalidad que recuerda el bello rasgo de Buckingham que nos cuenta Brantôme. Pocos escritores modernos tan ricos de imágenes, de metáforas, de toda clase de suntuosas figuras retóricas, como este joven que se empeña en hacernos creer que viene de Oriente [...]. Sus bengalas, sus gemas, sus fuegos no se agotan nunca y parecen salir de una urna mágica, consagrada a la abundancia perenne por un benigno hechizo» (Cansinos Assens, 1998: 287).

23. Dicha expresión alude directamente al hermoso poema titulado precisamente «Distinto» que escribiera Juan Ramón Jiménez: «Lo querían matar/los iguales,/porque era distinto.// Si veis un pájaro distinto,/ tiradlo;/ si veis un monte distinto,/ caedlo;/ si veis un camino distinto,/ cortadlo;/ si veis una rosa distinta,/ deshojadla;/ si veis un río distinto,/ cegadlo.../ si veis un hombre distinto,/ matadlo.// [...] lo que seas, que eres/ distinto/ (monte, camino, rosa, río, pájaro, hombre):/ si te descubren los iguales,/ huye a mí,/ ven a mi ser, mi frente, mi corazón distinto» (Jiménez, 2002: 340). 


\section{BIBLIOGRAFÍA}

Álvarez De Miranda, Ángel (1963), La metáfora y el mito, Madrid, Taurus.

CANSinos Assens, Rafael (1916), Estética y erotismo de la pena de muerte, Madrid, Renacimiento.

- (1982), La novela de un literato, vol. I, Madrid, Alianza Editorial.

- (1998), La Nueva Literatura. II Las Escuelas (1917), Obra crítica, Sevilla, Diputación de Sevilla, vol. I.

Casado Rigalt, Daniel (2006), José Ramón Mélida (1856-1933) y la arqueología española, Madrid, Real Academia de la Historia.

Cirlot, Juan-Eduardo (1985), Diccionario de símbolos, Barcelona, Labor, $6^{\mathrm{a}}$ ed.

CORREa RAMÓn, Amelina (1996), Isaac Muñoz (1881-1925). Recuperación de un escritor finisecular, Granada, Universidad de Granada.

GAUtiER, Théophile (1993), La Novela de la Momia, ed. de Alicia Mariño Espuelas, Madrid, Cátedra.

- (1863), en Journal des Goncourt, con fecha de 23 de noviembre de 1863, p. 124. Apud Litvak, 1985: 43.

GÓMEZ DE BAQUero, E. (1908), «Revista Literaria. Morena y trágica, El Imparcial (Madrid), 8 de junio.

GRARD, Dominique (1992), Imágenes de Andalucía y sus habitantes en la narrativa andaluza de principios del siglo XX (1900-1931), Sevilla, Don Quijote.

Gullón, Ricardo (1984), La novela lírica, Madrid, Cátedra.

- (1990), Direcciones del modernismo, Madrid, Alianza.

JimÉNEZ, Juan Ramón (2002), «Distinto», Antología poética, prólogo y selección de Antonio Colinas, Madrid, Alianza.

LiTVAK, Lily (1979), Erotismo fin de siglo, Barcelona, Antoni Bosch Editor.

- (1985), El jardín de Alah: Temas del exotismo musulmán en España, Granada, Don Quijote.

- (1990), «Exotismo arqueológico en la literatura de fines del siglo XIX: 18801895», España 1900. Modernismo, anarquismo y fin de siglo, Barcelona, Anthropos, pp. 231-244 (este artículo había sido publicado previamente en Anales de Literatura Española, Alicante, 4, 1985).

MÉLIDA, José Ramón (1884), La religión egipcia. Conferencia leída en el Ateneo Científico, Literario y Artístico de Madrid la noche del 6 de mayo de 1884, Madrid, Est. Tip. de El Correo.

MÉLIDA, José Ramón y LóPEZ, Isidoro (1880), El sortilegio de Karnak, Madrid, Casa Ed. de Medina.

MuÑoz, Isaac (1898), Colores grises, Almería, Tip. de Antonio Saldaña.

- (1906), Voluptuosidad, Madrid, Imp. de Emilio González. 
- (1908), Morena y trágica, Madrid, Imp. de Balgañón y Moreno. Existe una edición actual de la novela con los siguientes datos: Morena y trágica (1999), ed. y prólogo de Amelina Correa Ramón, Granada, Comares.

- (1914), Esmeralda de Oriente. Novela mogrebí, Madrid, Librería de la Viuda de Gregorio Pueyo.

- (1915), «La guerra en Oriente. El misterioso Egipto», Heraldo de Madrid (Madrid), 1 de febrero.

- (1997). La Serpiente de Egipto, edición, introducción y notas de Amelina Correa Ramón, prólogo de Ricardo Olmos, Madrid / Granada, Consejo Superior de Investigaciones Científicas / Diputación de Granada.

Ortega y GASSET, José (1923), El tema de nuestro tiempo, Madrid, Calpe.

ROMERO, Norberto Luis (2006), «El relicario de Lady Inzúa», en NAVARRO, Antonio José (ed.), La maldición de la momia. Relatos de horror sobre el Antiguo Egipto, Madrid, Valdemar, pp. 603-631.

SAGUAR QUER, Carlos (2006), «La Corte de Faraón: Egiptomanía en la arquitectura española», en González Alcantud, José Antonio (ed.), El Orientalismo desde el Sur, Barcelona, Anthropos, 2006, pp. 288-322.

SORBIER-RAWLS, Julie (2009), «Le Bestiaire orientaliste : symbolique occidentale des animaux d'Orient dans La Serpiente de Egipto d'Isaac Muñoz», Revue des jeunes chercheurs en Lettres, $n^{\circ} 3$ L'ange ou la bête, 2009, < http://www.rjcl.org/ revue/s.

VillenA, Luis Antonio de (2001), «Una gran novela decadente», Los andróginos del lenguaje, Madrid, Valdemar, 2001, pp. 195-196.

Fecha de recepción: 30 de abril de 2009.

Fecha de aprobación: 20 de mayo de 2009. 